\title{
The Meyhanes of Istanbul: A Cultural Value Struggling to Survive
}

\author{
Hüseyin Öney \\ Anadolu University Yunusemre Kampusu \\ Vocational School Culinary Program \\ Eskisehir-Turkey
}

\begin{abstract}
This study is based on meyhanes, which are the oldest form of food \& beverage facilities that strive to maintain the food \& beverage and presentation culture that has developed and evolved within the multicultural urban fabric of Istanbul for hundreds of years. As a result, the author determined what to be done in order to pass on these meyhanes of Istanbul to the next generation. Accordingly, oral history interviews were conducted with the operators of a few number of meyhanes, and with the investigative authors, who have been studying those meyhanes. Articles regarding the daily life and the nightlife in Istanbul, the scripts of travelers, memories of various authors and studies of historians were utilized as secondary sources.
\end{abstract}

Keywords: rak1, meze, food and drink, meyhane, meyhane operation, Istanbul

\section{Introduction}

Since alcoholic beverages are solemnly and strictly forbidden in Islamic regions, meyhanes tend to be considered commonly as accidental. This prohibition is one of the better known, even stereotyped, attributes of Islam (Tapper 2000:2015). Drink and meyhane has always featured prominently in urban settings, and in sophisticated literate and prosperous circles; whole cultures and etiquettes were generated around drink. A complete culture and tradition were constituted around alcoholic beverages (Zubaida and Tapper 2000: 1). When the Muslim Ottomans conquered Istanbul (1453), they prohibited meyhanes. Meyhane operation permits were only granted to non-Muslim minorities such as Greeks, Armenians and Jews. They worked as meyhane keepers for many centuries (Roden 2005: 140). A culture has been formed within centuries with its own table manners, food and beverages. Together with the Westernization and modernization of the Ottoman Empire, this culture began to change as from the second half of the $19^{\text {th }}$ century. Meyhanes became places where Muslims could also confessedly hang out, and even operate. Together with these changes, meyhanes began to turn into particular dining facilities with musical entertainment, such as clubs and taverns. While rakı became prominent instead of wine in meyhanes, the tables including cold and hot appetizers and rak1 started to be called çilingirsofrası (drinking bout).

The meyhanes of Istanbul, which has been a multicultural city throughout history, have always been places where the eating and drinking habits of various cultures were synthesized. With their unique ways of management, rules and rituals, meyhanes are considered as places pertaining to Istanbul. With the defeat and dissolution of the Ottoman Empire and the foundation of the Turkish Republic, non-Muslim minorities began to leave Istanbul after 1923 due to various political and social events. The immigration of the minorities operating those meyhanes, social and physical changes and transformation of Istanbul, increasing prices of alcoholic beverages, changes in consumption habits and the fluctuations in economic conditions all had a negative impact on meyhanes and their customers. The meyhanes, which tried to maintain the traditions despite of these changes, were replaced by public houses, bars and pubs and began to disappear. Despite these changes and transformations, a few meyhanes in Istanbul try to maintain their existence.

Various authors explained the dramatic conditions of meyhanes in last century; in 1947, Historian Koçu (2015) stated that the old meyhanes were no longer available. Investigative author Zat (2002) complained by saying, 'once upon a time, we used to have meyhanes'. Famous gourmet and author Şavkay (2002) stated in his column that 'now there are no more meyhanes, there are only bars'. In any event, since it is required by Islam, the conservatives have always been intolerant against alcoholic drinks and thus the meyhanes. With more than $118 \%$ of Special Consumption Tax on alcoholic drinks, $30 \%$ of recent price increase, and the spot-checking procedures on public houses, the meyhane operation becomes more difficult (Hür, 2011). The editor of Rakı Encyclopedia, Zat (2018) stated that 'we live in an era, where the meyhane culture is severely threatened, and this culture is desired to be annihilated completely'.

In addition to these problems, there are no written sources regarding meyhane operation, since the knowledge is transferred from father to son or from the master to the apprentice. Today, publications regarding meyhane, drinking culture and rakı are very recent. There are almost no academic publications. 


\section{Methods}

This study is based on meyhanes, which are the oldest form of food \& beverage facilities that strive to maintain the food \& beverage and presentation culture that has developed and evolved within the multicultural urban fabric of Istanbul for hundreds of years. It aims to reveal how the vanishing meyhanes resist recent oppression and to determine what should be done to carry this culture into the future. Accordingly, the evolution of meyhanes in the course of time is explained, and the author explained the criteria that make a public house considered as a meyhane, and how those meyhanes continued their existence with all of these changes and developments. As a result, the author determined what to be done in order to pass on these meyhanes of Istanbul to the next generation. Accordingly, oral history interviews were conducted with the operators of a few number of meyhanes, and with the investigative authors, who have been studying those meyhanes. Articles regarding the daily life and the nightlife in Istanbul, the scripts of travelers, memories of various authors and studies of historians were utilized as secondary sources.

\section{Meyhane: A Conceptual Overview}

Meyhane is composed of two Persian words: mey means 'wine', and hane means 'house'. In brief, the equivalent of meyhane is wine house (Ross 2011: 61). However, the meaning of the word 'mey' has expanded in time, and meyhanes became places where all sorts of alcoholic beverages, especially rak1, were consumed. Today, meyhane means 'a place, where all sorts of liquors are sold and consumed'. These definitions are very comprehensive. In order to provide a specific definition for meyhanes, the definitions of reference people are included. Zat states that in Turkey, meyhane is considered as a place where rak1 is consumed more than any other alcoholic beverage (Zat 2013: 76); Aras points out that meyhane is a place, where people drink, rather than eat, and the most popular alcoholic beverage, which is served together with various appetizers, is rak1 (Aras 2018). In another definition, Zat (2018) defines meyhane as follows: 'meyhanes are places, which couldonly emerge in a cosmopolitan city like Istanbul, and where a collective taste that has been ongoing for hundreds of years with its own appetizers, rules, and table manner has been synthesized and where a specific drinking culture is created, with no class distinctions, where everybody receives the same service'. According to Zat (2008), meyhanes are places with their own appetizers, conversations, manners, decoration, atmosphere, smell and table, where people go and drink rak1. Throughout the world, people with drinking habits have always formed sui generis public houses. Şimşek (2018) considers meyhane as authentic places, where the drinking tradition of the collective culture in Istanbul is maintained. Kalkan (2018) states that meyhane is the core of drinking culture, and this culture is the build-up of Dionysian culture, which has been living on many different cultures that have populated Anatolia for thousands of years.

Thus, according to these definitions, meyhanes are commercial food and beverage businesses, where the drinking cultures of many civilizations that go back to ancient times and dining behaviors of many nations and ethnic groups took form and were kept alive, and where alcoholic beverages that are intrinsic to Istanbul, especially rak1, become prominent. While alcoholic beverages were only consumed in meyhanes, people could now consume alcoholic drinks in many different places such as restaurants, bars, cafeterias and pubs. Therefore, it would be wrong to name every alcohol-serving facility as meyhane. In lexical meaning, meyhane is a place for drinking; however, not all those alcohol-serving facilities are called meyhanes. There are differences between meyhanes and alcohol-serving places. In order to understand this, we should take a look at those characteristics that make meyhanes special.

\section{Rakı and Meyhane}

Rak1 is the first element among others that are intrinsic to meyhanes. Wine has been replaced by rak1 over time in meyhanes in the Ottoman period, and a rak1 culture has been formed with its own traditions (Zat 1994b: 435). While this culture produced its own gastronomy, it also brought rak1 forward among other alcoholic beverages. Among other alcoholic beverages, rak1 is the most preferred drink in meyhanes. However, if certain rules are not followed (Zat 2008: 34), rak1 becomes a torment rather than give pleasure (Zat 2008: 7). The primary rule is that rak1 must be consumed with certain food. This obligation makes it the one and only drink for which a specific cuisine has been developed (Belge 2001: 83). Another property of rak1 is that while the type of wine is selected in accordance with the food, the food is selected according to rak1. Rak1 has a personality and it imposes its own rules (Belge 2001: 83). Because of these rules, until quite recently, rakı has also remained as a masculine drink, just like meyhane. It is believed that Turkish men take their strength from rakı, and the epithets of 'aslansütü' (lion's milk) are signs of this strength (Kliç 2012: 88). Rak1 is even considered as the national drink.

While rak1 is a mere product of meyhane, meyhane has also evolved with rak1. Although people can drink anywhere and anytime, rak1 requires a certain and specific setting (Belge 2001: 87). In other words, people drink rak1 within a certain table setting, and like to have long conversations while drinking. The culture, which has risen and developed through this table setting, constitutes the essence of meyhanes with its conversations, service, appetizers, decanter and glasses (Zat 2014: 7). 
Since rak1 is a strong drink that contains high levels of alcohol, it should be consumed with some certain food stuff through the long hours of drinking. However, these foods are not consumed to get full, but to accompany rak1. The foods that are served with rak1 are called the appetizers (meze). Food products served in meyhanes that accompany rak1 increase thirst with an aim to increase the time spent by the customer in meyhane. The foods in meyhane are either prepared before hand, or prepared quickly and are ready to be consumed.

\section{Meyhane and ÇilingirSofrası (Drink Bout)}

Appetizers are the other criteria that make meyhanes special. Only the appetizers are served in meyhanes and, unlike in regular restaurants, main dishes are not consumed with drinks, especially with rak1. Consuming a main dish along with rak1 is a post-modern phenomenon that emerged as the public houses became more popular and as they were replaced with traditional meyhane culture (Belge 2008: 86). Kalkan (2018) states that there are no main dishes in meyhanes, and there are also no menus; this is because people would not choose from a menu and order in meyhanes. The appetizers have reached a wide range of variety over hundreds of years. Despite this diversity, according to consonance that has been reached since those days when rak1 was the primary drink in meyhanes, the most preferred rak1 appetizers have always been feta cheese and melon. The rest of the appetizers vary in accordance with the financial status of the customer. Some people even prefer lobster or caviar as appetizers. Again, the collective taste underlies this diversity. It is easy to see this in types of appetizers. Spiced mutton liver (Arnavutciğeri), Circassian chicken (Çerkeztavuğu), topik from Armenian cuisine, leek balls (pırasaköftesi) from the Jewish couisine, and Greek bonito pilaki (palamutpilaki) are among these appetizers.

The appetizer plates in traditional meyhanes may be oval, square or rectangular, but these plates are always small in size. For example, Zat (2018) when the customer orders zeytinyağlı dolma (stuffed pepper with olive oil), only one dolma is served on a plate together with tomatoes, lemon slices and parsley. These plates do not intend to satiate the customer, they are rather for taste. These humble tables that contain appetizers served in small plates are called 'çilingirsofrası' (drink bout) (Zat 2008: 89). Çilingirsofrası, which has been the common ground of all meyhanes, is one of the most significant elements of meyhane culture and drinking rak1. The appetizers are not served per person; rather, the appetizer plates are placed in the middle of the table and shared by everyone on the table. This symbolic sharing is the key for solidifying friendship, sharing feelings and ideas, spending good time, i.e., for the type of entertainment that makes meyhanes special.

\section{Meyhane Operator}

Muslims always refrained from being meyhane operators or employees. Since bar keeping was considered as an unfavorable job among Muslim Turks, they began to work as bar keepers, employees or cooks only after 1910. Many of the meyhane operators and employees in Istanbul were of Greek origin. In Armenian or Jewish neighborhoods, the bar keepers were also Armenian or Jewish. Regardless of the ethnic origin of the minority group, the titles and names used by the Turks for meyhanes and their employees were always in Greek or Greek-like names. The owner of the meyhane was called Barba, and the counterman was called mastori (Zat 1994, 434), which is the equivalent of presentday bartenders. Sometimes barba overtook the job of mastori and he was also called mastori (Koçu 1971; Zat 1994). Since meyhane operation had never been considered as a reputable job, the owners had never written 'meyhane' on the signboards, and those places were generally referred to by the actual names of the operators. E.g. 'Despina's', 'KörAgop's (Zat2018).

Commercially, meyhane is a business and the bar keeper (meyhaneci) is a type of tradesman. However, when bar keeping is performed with the notion of earning a lot of money without sufficient experience and cultural knowledge, things could go wrong operationally (Arslan 2018). Bar keeping is not something that you can learn by trial and error, and it does not yet have a school or a book (İnciyan 2018). It should be learned from the family or through practical experience by working in a meyhane. Besides professional experience, the most important thing is to love your job in order to operate a meyhane. Unless the philosophy of meyhanes is adopted, and the operator loves his job, it would not be considered bar keeping in real terms (Kalkan2018).

The bar keeper should know meyhane culture and philosophy, should love people, should be considered a gourmet in his field, should have good communication and human relations skills, should know and implement the social good manners, ethics and trade very well and should have good managerial skills. Because the bar keeper is the person, who sets and adopts the codes of conduct for a public house.

On the other hand, the rules of meyhanes require being a social person, and acting in accordance with collective ethics and etiquettes within society (Zat 2018). The ones, who love their jobs and do it by knowing all of these by heart, can be real bar keepers. Since there are a few real bar keepers left, they have high social value (Kalkan2018). Real bar keepers are respected as a famous artist or a statesman (Arslan 2018). The services received in an original meyhane 
ensure psychological relief and comfort (Şimşek 2018). Today, even though the bar keepers do their jobs eagerly and professionally, they are having hard times against various environmental issues.

\section{Problems Encountered by Meyhane Operators}

Human beings have consumed alcoholic beverages for thousands of years. This habit maintained secretly even though it was opposed and completely prohibited in some communities and beliefs, but the importance of alcoholic beverages for relief and encouragement of socialization has been emphasized in many communities (Chrzan 2013). Consumption of alcoholic beverages is strictly forbidden in Islam. Through opportunities provided by secularism in the Turkish Republic, everyone can consume alcohol and go to public houses as long as they abide by the laws and regulations. As in the Ottoman Period, there were even many literary works that eulogize alcoholic drinks and meyhanes. Since literary works that eulogize and dignify meyhanes belong to the authors who loved drinking and meyhanes, they were nonobjective eulogies. However, as it was in the past, the prestige and respectability of meyhanes are still debated by a vast majority of the society. Meyhanes have always been perceived as the sinks of iniquity by a vast majority of the society (Aras 2018). As a matter of fact, conservatives have always considered meyhane as a concept that refers to ethical decadence (Zat 2018). Şimşek (2018) expressed this negative perspective as follows: 'If our great grandfathers were alive today, they would have teased us as whoremaster. They would have always thought of bar keeping as a concept that reminds of brothel keeping' (Şimşek 2018). Although meyhanes were adopted and were once more popular, and the bar keepers were respectable and lovable the regulars of the meyhane it had never been considered as respectable as other acceptable and recognized occupations, such as butchery, bakery or grocery business. Therefore, women could not go to meyhanes until recently because of their bad reputation; there were also not any female employees, cooks or waiters. This may be considered as another form of expression of social perception against meyhanes

The elites of the Ottoman Empire had particularly avoided the word meyhane, and prefer to implicitly use the name 'şerbethane', which was used for places that offer soft drinks (Balıkhane Nazır1 1973: 287). This is because society would frown upon people who would go to meyhanes in daily life. Depending upon these reactions, the gedikli meyhanes of the past did not have signboards as signboards said pub or restaurant until recently (Zat 2014). The conservatives have always been sensitive regarding alcoholic drinks and meyhanes. However, an increasing trend is observed when the alcohol consumption statistics are reviewed. While the drinkers prefer out-of-sight vineyard houses or rural restaurants in order to drink comfortably in places with extreme religious oppression, the places operated as meyhanes try to maintain a low profile and continue to exist as cafeterias or hotel restaurants (Zat 2014).

Bar keeping has always been an occupation that is taught within the mentor-protégé relationship. Let alone writing a book regarding this matter, it was even strictly forbidden to take notes in traditional mentor-protégé training systems (Ünsal 2002: 105). But İstanbul there has been a deep-rooted alcoholic drink manufacturing and consumption culture that started with beer and wine manufacturing (Morgül 2014). When they began to work for rak1 encyclopedia, Zat (2014) mentioned that the literature regarding meyhane and drinking culture was like a desert. This does not only apply to literature. Istanbul's structure and the relations between people were also desolate.

\section{Meyhane Operator}

Muslims always refrained from being meyhane keepers or employees. Since meyhane keeping was considered as an unfavorable job among Muslim Turks, they began to work as meyhane keepers, employees or cooks only after 1910. Many of the meyhane operators and employees in Istanbul were of Greek origin. In Armenian or Jewish neighborhoods, the bar keepers were also Armenian or Jewish. Regardless of the ethnic origin of the minority group, the titles and names used by the Turks for meyhanes and their employees were always in Greek or Greek-like names. Meyhaneowners were first known as barba (an Italian word literally meaning 'bearded man'). Barba were usually kind, talkative, humoristic, yet paternalistic older men. Mastori is a person who formulates and serves usually beverages behind the bar which is the equivalent of present-day bartenders (Zat, 1994: 434). Since meyhane operation had never been considered as a reputable job, the owners had never written 'meyhane' on the signboards, and those places were generally referred to by the actual names of the operators. E.g. 'Despina's', 'KörAgop's (Blind Agop's)' (Zat 2018).

Commercially, meyhane is a business and the meyhane keeper (meyhaneci) is a type of tradesman. However, when meyhane keeping is performed with the notion of earning a lot of money without sufficient experience and cultural knowledge, things could go wrong operationally (Arslan 2018). Meyhane keeping is not something that you can learn by trial and error, and it does not yet have a school or a book (Inciyan 2018). It should be learned from the family or through practical experience by working in a meyhane. Besides professional experience, the most important thing is to love your job in order to operate a meyhane. Unless the philosophy of meyhanes is adopted, and the operator loves his job, it would not be considered bar keeping in real terms (Kalkan 2018). 
The meyhane keeper should know meyhane culture and philosophy, should love people, should be considered a gourmet in his field, should have good communication and human relations skills, should know and implement the social good manners, ethics and trade very well, and should have good managerial skills. Because the meyhane keeper is the person who sets and adopts the codes of conduct for a public house. On the other hand, the rules of meyhanes require being a social person, and acting in accordance with collective ethics and etiquettes within society (Zat 2018). The ones, who love their jobs and do it by knowing all of these by heart, can be real meyhane keepers. Since there are a few real bar keepers left, they have high social value (Kalkan 2018). Real meyhane keepers are respected as a famous artist or a statesman (Arslan 2018). The services received in an original meyhane ensure psychological relief and comfort. In any case, it is cheaper than seeing a psychiatrist (Şimşek 2018). Today, even though the meyhane keepers do their jobs eagerly and professionally, they are having hard times against various environmental issues.

\section{Problems Encountered by Meyhane Keepers}

Human beings have consumed alcoholic beverages for thousands of years. This habit has been maintained secretly even though it was opposed and completely prohibited in some communities and beliefs; however, the importance of alcoholic beverages for relief and encouragement of socialization has been emphasized in many communities (Chrzan 2014: 1). Consumption of alcoholic beverages is strictly forbidden in Islam. Through opportunities provided by secularism in the Turkish Republic, everyone can consume alcohol and go to public houses as long as they abide by the laws and regulations. As in the Ottoman Period, there were even many literary works that eulogize alcoholic drinks and meyhanes. Since the literary works that eulogize and dignify meyhanes belong to authors who loved drinking and meyhanes, they were nonobjective eulogies. However, as it was in the past, the prestige and respectability of meyhanes are still debated by a vast majority of the society. Meyhanes have always been perceived as the sinks of iniquity by a vast majority of the society (Aras 2018). As a matter of fact, conservatives have always considered meyhane as a concept that refers to ethical decadence (Zat 2018). Şimşek (2018) expressed this negative perspective as follows: 'If our great grandfathers were alive today, they would have teased us asbastard. They would have always thought of bar keeping as a concept that reminds of brothel keeping'. Although meyhanes were adopted and were once more popular, and the meyhane keepers were respectable and lovable to the regulars of the meyhane, it had never been considered as respectable as other acceptable and recognized occupations such as butchery, bakery or grocery business. Therefore, women could not go to meyhanes until recently because of their bad reputation; there were also not any female employees, cooks or waiters. This may be considered as another form of expression of social perception against meyhanes.

The elites of the Ottoman Empire had particularly avoided the word meyhane, and prefer to implicitly use the name 'şerbethane', which was used for places that offer soft drinks (Ali Rıza Bey 1973: 287). This is because society would frown upon people who would go to meyhanesin daily life. Depending upon these reactions, the gedikli meyhanes of the past did not have signboards as signboards said pub or restaurant until recently (Zat 2018). The conservatives have always been sensitive regarding alcoholic drinks and meyhanes. However, an increasing trend is observed when the alcohol consumption statistics are reviewed. While the drinkers prefer out-of-sight vineyard houses or rural restaurants in order to drink comfortably in places with extreme religious oppression, the places operated as meyhanes try to maintain a low profile and continue to exist as cafeterias or hotel restaurants (Zat 2018).

Meyhane keeping has always been an occupation that is taught within the mentor-protégé relationship. Let alone writing a book regarding this matter, it was even strictly forbidden to take notes in traditional mentor-protégé training systems (Ünsal 2002:105). This approach means that there is not a single written information regarding this matter, although in Anatolia, the cradle of civilizations, there has been a deep-rooted alcoholic drink manufacturing and consumption culture that started with beer and wine manufacturing (Morgül 2018). When they began to work for RakıEncyclopedia, Zat (2018) mentioned that the literature regarding meyhane and drinking culture was like a desert. This does not only apply to literature. Istanbul's structure and the relations between people were also desolate.

\section{Customers and Changing Culture}

In the final century of two thousand years of magnificent and swarming history, a woeful cultural desolation has become an issue. The city that witnessed two empires has become a part of a nation state in the first half of the century. The ideology, and thus the architecture, size, migration structure, settlement and consumption patterns have all changed. Therefore, while strict, dismissive and authoritative places were created with these transformations, meyhanes began to lose their regular customers (Margül and Saç 2012).

Consequently, the regulars are replaced with customers and meyhanes having regular customers and offering service as per requests and expectations of those regulars are disappearing. The reason is that there are not any regular customers and any people, who show respect and tolerance to others (Aras 2018). In today's consumption patterns, it becomes significant where and with whom people go out, and friendship is replaced by formalism. 
With the widespread use of communication technologies and social media, people not only consume, but they also share what they consume. This means the hangouts and companions are ever-changing. Meyhanes, which has a conventional foundation for hundreds of years, cannot be expected to resist these changes (Morguil 2018)). Since the customers of meyhanes do not know each other within today's cosmopolitan structure of Istanbul, they go to meyhanes in groups. This is against the nature of a meyhane. Those were the days when the fifth person sits at a table for four, and feels uneasy thinking if he disgraced the bar keeper, and those days are over (Aras 2014). While in the past two unacquainted tables were able to become friends later in the night, it is almost impossible to form that kind of a relationship today (İnciyan 2018). The reasons should be sought in social and urban transformations in Istanbul.

In the past, fish from the Bosporus, and various seasonable ingredients coming from Istanbul and its vicinities were used in meyhanes. Now the fish types and other food stuffs of Istanbul are no more available. The ingredients are now brought from afar or imported (Kizlltay 2018). Additionally, when poor cultural recollection and economic concerns are involved, things become more distorted (Aras 2018). Changing modes and patterns of consumption impact the modes of production. With unconscious consumption, seasonal and natural ingredients were replaced with convenience foods (Morgül 2018). With industrialized food stuffs and appetizers produced in factories, standardization of taste and quality and similar foods and services offered in all places are eliminating traditional bar keeping business.

\section{Poor Management}

Meyhanes are bars, rather than restaurants. Today, some meyhanes have been in the process of evolving into restaurants. Although rak1 is consumed together with meal, the restaurants, where meal remains in the forefront, became mainstream (Zat 2018). Meyhanes are becoming a thing of the past and giving way to public houses. This is led by ever-changing consumption habits (Aras 2018). In the Republic periodtraditional meyhanes failed to stand against bars and their numbers reduced especially after 1970s and 1980s, many were replaced with modern restaurants and bars. It is certain that ever-changing and developing drinking culture has an influence on this (Zat 1994, 437).

With the changes in eating and drinking habits, meyhanes are forced to shut down or to go through substantial changes. Old meyhanes were epochal with their unique culture, and now they are reshaped by new trends. This change occurs as gradual transformation of meyhanes into bars/restaurants that offer musical entertainment. Unlike places such as discos that offer musical entertainment, the main purpose in original meyhanes is to have long conversations. Set meals, birthday parties, celebrations, and parties began to be popular after the mid-1980s (İnciyan 2018). These practices are against the traditions and philosophy of meyhanes (Kalkan 2018). The worst part is when people offer low-quality service with poor management to gain more profit without even considering the rules, laws, culture and history of meyhanes. That a certificate of expertise or a license is not required for the bar keeping business causes problems that may toll the death knell of this profession (Aras 2018). While bar keeping used to require expertise in the past, this quality is not sought in this businessnow. This practice may have positive contributions (Aras 2018). It is necessary to prevent unqualified people from working in the bar keeping business, to seek for experience and at least to stipulate proper training (Arslan 2018). Unfortunately, these practices depend on legislations. The relationship between the state authority and meyhanes has never been a good one. It is still unknown whether the state authorities will make an effort for a legislative regulation to impose a competence or license obligation for prospective bar keepers.

\section{State Authority and Meyhane}

At first, meyhanes were not such places where people had a couple of drinks and chit chatted. They began to be such places gradually as from the late $16^{\text {th }}$ century (Y1lmaz 2005). As the social function of meyhanes in public sphere increased, a period of prohibitions and shut downs had begun in Istanbul. Economic prohibition used to be abolished after a while due to its negative effects on the treasury (Turan 2012). There have been many prohibitions on alcoholic beverages, and meyhanes have been closed down many times in Istanbul. Rather than an opposition for alcoholic beverages or the piety of the emperor, these prohibitions should be considered within the same frame as prohibitions on newspapers in the same era (Ortayl 1986, 88). Until recently, meyhanes were social spheres, where people listen to what others said, rather than chattering and speaking without even listening. These people would also listen to the ones who would talk against the state administration. These hearsays were called the rumors on the state. The people, who unsealed their lips within the comfort of the meyhane, would begin to politically criticize the government politically. The rulers, who never liked those rumors on the state affairs, closed down meyhanes by propounding the strict rules of Islam regarding alcoholic beverages (Ortayl1 1986, 88).

Similar practices are still common in this day and age: High taxes levied by the government on alcoholic beverages in 2010, prohibitions on alcoholic beverages in recreational facilities governed by the municipalities of the ruling party, publicly owned social facilities and private facilities within campuses, tirades of some authorities regarding the damages caused by alcoholic drinks, 
Prohibition of alcoholic beverages in official meetings, increase of the tax rate of rak1 to $118 \%$ with $30 \%$ of increase in Special Consumption Tax of alcoholic beverages, and raids by police forces to public houses in many cities disturb the regulars and the operators (Hür 2011). This attitude against the alcoholic beverages is considered as an action against drinking culture and meyhanes (Morgül 2018). It is inexplicable that the bars, restaurants and cafes listed as 'places that serve alcoholic beverages' in Tobacco and Alcohol Market Regulatory Authority's database do not wish to promote their places and have more customers. Except for governmental constraints such as decertification, it may also be perceived as an indicator of a widespread peer pressure (Zat 2018). These are all made to save the society from the clutches of alcoholism. According to Ortaylı (1986) in order to prevent Turkish society from being enslaved by alcoholism, it is necessary for the society to experience meyhane culture. Eating the appetizers slowly without gobbling, and reducing the number of glasses consumed, i.e. preserving the drinking manners should be supported as the most robust and effective way against alcoholism.

With excessive increases and taxes, meyhanes of Istanbul are having their most expensive period ever. Customers spend most of their money on drinks. When the drinks are expensive, many operators, who do not want to strand their customers with prices, prefer cheap appetizers manufactured in catering factories, or reduce their profits. Ready-toserve foods bring along the risk of endangering the appetizer culture and taste in meyhanes (Şimşek 2018).

Another significant issue is standardization of Istanbul based on political events. This standardization began after the 1950s and 60s, and 99\% of non-Muslims, who had significant roles within the city culture for thousands of years, had left the city. Meyhanes and their culture had disappeared, which had always been intertwined with the living space (Morgül 2018). When conservatism began to prevail after the military coup d'état of September 12/1980, entertainment and drinking began to be restricted in some certain regions of Istanbul. Aiming to create a tourism district, this project became a result of the perspective of the local authorities (Morgül 2018).

Tekin (2018), who has been holding office in the Planning Board of Istanbul Municipality, states that the entertainment zone project was initiated for a good purpose, and the pilot (development) area was Kumkapi district. Tekin (2018) also states that the project, which was created based on the examples in Europe, especially in Paris, was misapplied.As in many districts of Istanbul,it is observed that restricting nightlife within a certain area was a bad idea because the practices of one place may disturb the customers of another place. The owner of Refik restaurant in AsmaliMescit Street, Arslan (2018) states that many residents and tradesmen left the street due to increasing rental prices and disturbance caused by the bars that are blasting music after the street was declared as the entertainment area, and complains that the friendship among the fellow tradesmen is long gon. Şimşek (2018), who worked as a professional tour guide for many years states that the meyhanes in Kumkap district were included within the tour plans until the 90s, however this became impossible due to changing tourist profiles and costliness, and also states that compared to the past, the quality of service has been reducing drastically (Şimşek 2018).

The most significant loss regarding the meyhanes of Istanbul and meyhane culture is the immigration of Greeks. Greek bar keepers have always been the best executors of the bar keeping business with their approach to human relations, communication and service skills, and cuisine and management cultures. Together with Atatürk, the founder of Modern Turkey, alcoholic beverages and drinking culture became unconstrained and people began to take interest in drinking. Despite this interest, the Greeks could never maintain bar keeping business in the upcoming years due to political oppressions and social events (Tekin 2018). Although the disciples of the last Greek bar keeping masters, or the ones who had the necessary knowledge, tried to operate their own meyhanes, the number of real bar keepers and barbas has reduced dramatically. Morgül (2018), who visited hundreds of meyhanes for his meyhane guide and documentaries, states proudly that there are still some real meyhanes in Istanbul, despiteoppression and bad experiences.

Although some still survive today, meyhanes of Istanbul are experiencing difficult and lean times with price increases, oppression, and customer expectations changing with the new entertainment center projects. It is still unknown whether these few meyhanes will be able to transfer their knowledge and experiences to the next generations. Professionals, academicians and researchers have great responsibilities regarding this matter. However, academic circles do not seem interested in meyhanes and drinking culture. The related publications are at beginner-level. İnciyan (2018) complains about the food and beverage professionals' approach to meyhanes and bar keeping business, and states that the professionals consider meyhanes as their distant relatives, with whom they are acquainted but never visit.

Taken together, a few real meyhanes, where the culture related to alcohol consumption on these lands for thousands of years has been preserved and maintainedideally are not supported for their struggle for survival.

With the reconstitution of the law on sales and consumption of alcoholic beveragesin 2013, the alcoholic drink manufacturers have had limited permission for sponsorship, training organizations and for sponsoring cultural publications. These limitations mean the budgeted studies, which will make major contributions to drinking and meyhane culture, are not supported. 


\section{Survival Struggle of Meyhanes}

Although some people think that meyhanes look gloomy, it has always been acknowledged that there is something heartwarming and pleasant in meyhanes. This is the shared decision of all right-minded gourmets, who do not have any prejudices against alcohol (Şavkay 2002). It is the same as it was in the past. Today's unfortunate truth is that the number of Greeks, who are still praised for practicing this occupation properly for many years, and the number of other bar keepers, who are almost as good as those Greeks, has reduced drastically. However, the meyhane culture carried on by the Greeks still lives today; this is what upon which we should focus. The culture developed by Greek bar keepers still lives. Kalkan (2018) responds to this by saying: 'No one is able to destroy this culture completely'. Zat (2018) shares the same view with Kalkan (2018) and states that rak1 is a culture-specific drink; the authorities may try to prevent alcohol consumption by price increases or prohibition, but rakı and meyhane culture and çilingirsofrası cannot be destroyed completely.

Meyhanes are transforming and changing. The hovel meyhanes of yesterday became today's luxury restaurants and bars, and this is only a formal transformation. These transformations and changes are perceived as better developments, as long as the specific values of meyhanes are preserved. Bar keepers and employees have great responsibilities regarding the protection of these values. The bar keeper should have principles and should not compromise these principles in order to operate a real meyhane and to maintain its existence and to continue to be successful for generations. According to the common view of the reference people interviewed within the scope of this study, the secrets of a successful meyhane are listed as follows.

Taste and flavor come first and they should be natural. The appetizers should be daily and fresh, and should be as seasonable as possible. Nothing unapproved should be served. A good supplier should be selected for high-quality materials. Bar keepers should focus primarily on service, not on money. They hould have good relations with their customers, as well as their employees, and they should not change personnel so often. Bar keepers should take care of their businesses, and should prepare an atmosphere, where the regulars feel like home, and should not exaggerate the interior design and decoration. Bar keepers should be generous, and should offer treats. They should not be tightfisted and should not charge water, bread, or a slice of lemon. They should never be driven by the ambition to make more money. The first principle of bar keeping is to have an affordable price policy. Most importantly, the bar keepers should love their job. Just like the bar keepers, the employees should also love their jobs; they should act naturally and customer relations should be based on sincerity and honesty. The interior design of the meyhane should not be extreme; simplicity is the best décor. It should always be remembered that meyhane is not a Champs-Élysées pavilion. The only music should be the background music, and other types of music should be left to customers' discretion. Groups of 1020 people should never be allowed in; if they are, they should be seated at different tables in smaller groups and fixed menus should be avoided. The bar keepers should be aware fact that they carry meyhane culture into the future and should also know the culture and history of the bar keeping business.

İnciyan (2018) emphasizes that each bar keeper should have principles and policies, and no problems are encountered in such meyhanes, which abide by their principles and where the customers feel comfortable. Zat (2018) and Kalkan (2018) states that they have been putting an effort to create a place in his meyhane, which was opened in 1890, and which acts as a bridge to maintain meyhane culture and to carry this culture into the future, and they make no concessions on their rules and principles. Contentment, comfort and satisfaction of the customer are important factors. However, the customers should be properly informed that the essential form of presentation and philosophy of meyhane culture should not be ignored. While Kalkan (2018) states that meyhane operation is very difficult in these terms he also states that they put so much effort against belly dancing and percussion dancing, and against people, who would like to come in groups for celebrations of special occasions, which are against the grain of the philosophy of meyhanes.

Bar keepers should also know how to resist industrial products and appetizers. The traditional appetizers, which have gone through thousands of years and reached present day, should never be easily bartered away. Şimşek (2018) statesthat they stick by the original flavors of traditional appetizers, and if any changes or arrangements are made on appetizers, they serve that appetizer under another name, and they try to include mostly traditional appetizers. The bar keeper is both the protector and the developer of this culture. Kalkan (2018) that we should be open to new tastes and fusions, but these new tastes should not be presented to the customers without any preliminary testing process.

Meyhanes, which are torn between their obligations to preserve the tradition and to comply with changes and transformations, bring their own solutions for this problem. According to Inciyan (2018), ignoring the wishes and expectations of the customers, which undergo changes with social and cultural transformations, may cause problems. Şimşek (2018) that it is necessary to adjust, to adapt the physical environment according to the conditions, and to even use and computer technologies when necessary. 
Tekin (2018), who states that the regulars and the employees are the elements that make a meyhane special, points out that the most important mission of bar keepers is to carry this meyhane culture into the future, which may be considered as an intangible cultural heritage, by pushing aside their ambition to make more money. The mission of carrying meyhane culture into the future was the common view of the reference people interviewed within the scope of this study, and the existence of meyhanes depends somewhat on their regulars as well. Another purpose of bar keeper against the high prices of alcoholic beverages is to retain their regular customers. As a solution, all bar keepers should try to keep the prices as low as possible within the bounds of possibility, and try not to reflect those excessive prices onto their customers. With this low-price policy, as long as the employees work willfully and are aware of meyhane culture and history, meyhanes will continue to have new regular customers and retain the existing ones and thus, meyhane culture will continue to exist.

Bar keeping is an archaic culture. It is also somewhat stressful because it is a very difficult job. It is learned through a mentor-protégé relationship under very difficult conditions. Arslan (2018) complains that it is getting harder to find young people, who will roll with the punches work hard and learn this job. Increasing numbers of the schools offering food and beverage and gastronomy programs in Turkey create an opportunity that may provide a solution for this problem. Although they were a few in number, the schooled/educated began to get involved in this business. Educated employees are expected to facilitate the bar keeper's work. However, the graduates do not yet have a strong interest in bar keeping. Inciyan (2018) states that he works with culinary arts graduates in his meyhane and suggests that meyhanes should be explained thoroughly in gastronomy schools and the students should know that meyhanes are not bad places at all. Inciyan (2018) also states that there is no book to teach you how to become a bar keeper, but even if there is a book, it cannot be learned by reading the book; bar keeping can only be learned by practicing after the first ten years. Şimşek (2018) points out that bar keeping can only be learned in meyhanes, and the novices, cooks, waiters and bussers can only gain experience by working in meyhanes. Kalkan (2018) emphasizes the difference between production and services offered in meyhanes, and points out that bar keeping education is distinctive and this education should cover a number of subjects because a restaurant waiter should go through a different education in order to work in a meyhane, Examples of these subjects are Eastern culture, history, production and origin of the appetizers offered in meyhanes, health and nutrition, the place and importance of meyhanes in ethnology, and the origin, production and presentation of the drinks. Zat (2018) points out that the mentor-protégé training system has already expired in bar keeping business and now the employees are required to receive culinary arts education or a higher-level gastronomy education. In order to prevent unqualified people from engaging in this business, Aras suggests that stipulating license and professional competence conditions as in gedikli system will contribute to the solution.

Another significant development, which made a great contribution to existence and widespread recognition of meyhanes, is the increasing number of publications and productions that increase the knowledge in this field. The publications and productions such as blog posts, columns and reports that praise and exalt meyhanes, rak1 encyclopedia, rakı book, meyhane guide and meyhane documentary arouse curiosity and interest about the meyhanes. Morgül (2018) states that he not only shoots documentary films or writes books in order to prevent this historical and specific culture from vanishing into mists of time, he also informs people and tells them about meyhanes everywhere he goes. When meyhanes began to catch on with people and to be rediscovered along with the intellectual knowledge that has been developed with the publications and narrations of other contributors like himself, meyhane owners, who preferred to avoid using the name 'meyhane' ten years ago, began to name their places as 'meyhane'. As the number of publications continues to increase, Şimşek (2018) anticipates that originality, authenticity and taste have begun to be significant elements of attraction for meyhanes, and now gourmet meyhanes are becoming more popular. The editor of rak1 encyclopedia, Zat (2018) states that when they began to prepare rak1 encyclopedia, there were almost no other studies regarding meyhane, rak1 and appetizer culture, and the existing knowledge was disorganized. However, he also states that some articles were written by distinguished group of scholars and researchers, and the encyclopedia was prepared to lead a cultural leap. Morgül (2014) states that the publications regarding this field began to achieve their purpose, and the places, which had been using the words restaurant or seafood restaurant instead of meyhane on their signboards until a decade ago, began to call themselves meyhanes together with the increasing interest and popularization of these publications. Zat (2018) states that each action comes with its own reaction, and in this negative environment regarding the meyhane culture, the number of places, which began to proudly call themselves 'meyhanes' and began to use the word on their signboards, have increased.

As the authorities continue to prohibit and suppress rak1, it becomes more in the limelight; the young generations also beginn to grow more interest and curiosity, which may lead them to become future regulars. Tekin (2018) states that he is pleased with the positive reaction of the rising generation regarding meyhanes and the meyhane culture. 
According to Tekin (2018), in order to maintain the existence of meyhanes for many years, a municipal administration, which is aware of the importance of meyhanes within the urban culture of Istanbul, must be in the saddle. Tekin (2018) also states that meyhanes and meyhane culture should be suggested as research subjects for academic studies. Meyhane culture is a significant value within Turkish food and beverage culture, which should be included within the scope of intangible cultural heritage with the help of a study group that will be constituted by the Ministry of Culture and Tourism.

Pecuniary principles of meyhane come from the ancient times. This culture brings the food and beverage products of many different nations and ethnic groups together and keeps them in stock. Other than tens of different food and beverage products, it also has basic gastronomy principles and rituals regarding what would be consumed where, when, how, for what occasion and with whom. All food and beverage products in its repertoire are brought to perfection in hundreds of years through the synthesis of a collective taste. Pursuance of meyhane culture by a few successful operators' efforts is a praiseworthy occasion. Such culture is so valuable and heavy that it cannot be put on the shoulders of a few operators, despite their good intentions. Efforts should be made to shine this cultural treasure of Istanbul and this region, to turn it back to its good old days and to make it easily accessible.

\section{Results}

Meyhanes of Istanbul has left its old popularity behind. Meyhanes went through their darkest age in the 1990s. The opportunity to get back to its sumptuous days in the 2000s decelerated with excessive price increases on alcoholic beverages. Meyhanes began to draw interest together with the publications regarding meyhanes and rak1, such as Meyhane Guide, Rak1 Encyclopedia and Rak1 Book. After 2010, when the number of publications began to increase, manufacturers of alcoholic drinks and public houses were prohibited from advertising, sponsorship, and cultural publications. Together with these prohibitions, the manufacturers of alcoholic drinks became unable to support publications regarding meyhanes and drinking culture. Authors and producers lost their primary sponsors, which supported big-budget publications and documentaries. These unfavorable conditions began to be overcome by publishing and broadcasting articles and videos in web sites with thousands of followers, by memories and observational articles posted in blogs, and by effective use of the Internet and social media.

These developments indicate that while a considerable number of Turkish people keep away from alcoholic beverages as required by Islamic beliefs, the remaining part of the population is interested in consuming alcoholic beverages, especially rak1, and going to public houses. This is because this region still holds a tradition, a habit and a culture of drinking that began with oenology and has been going on since the ancient times. In meyhanes, which were originally aimed for consumption of alcoholic beverages, psychological and social functions become more prominent beyond drinking. When the alcoholic drinks are consumed within a set of rules and rituals, meyhane environment offers its customers the opportunity to relax, cheer up and to enjoy what they eat or drink. Rather than stimulating alcoholism, the long hours spent in meyhanes create an effect that may prevent alcoholism.

Despite the opportunities offered by meyhanes, many were forced to shut down due to environmental factors. Even the historical buildings of those meyhanes were demolished. Despite all these shut-downs or ruinations, many more meyhanes are opened each day. The society has always been interested in consuming alcoholic beverages. Rak1, which is considered as the traditional drink, is one of the most consumed alcoholic beverages. The rituals and table manners imposed by rakı necessitate the meyhane environment unavoidably. In a society, where rak1 is the most consumed beverage, it is impossible to think that meyhanes would sink into oblivion. Rather than disappearing, meyhanes of Istanbul began to transform with the concerns of offering service to ever-changing population and consumption habits. While many transformed into musical entertainment centers, some became restaurants. Only a few places maintain the bar keeping business in real terms. What is more important is not the changes in drinking habits, but the disappearance of places which have been maintaining a culture that dates back to the ancient times.

Istanbul had been the capital of many empires, and the city is surrounded by fertile seas and lands where so many different cultures had lived together for hundreds of years. Meyhanes of Istanbul developed with the opportunities provided by the city itself. What is called the real meyhane is this cultural heritage. This cultural heritage is protected by the love and vision of a few operators. Meyhanes had never had good relations with the state authority. And no academic works were published regarding the meyhanes of Istanbul, meyhane culture, appetizers and their gastronomy under the disciplines, such as tourism, food and beverage, sociology and ethnology. The studies made were the works of investigative authors published with the support of some sponsors. Unfortunately, the knowledge that will contribute to protection of meyhanes and meyhane culture is not sufficient.

On the other hand, while the number of gastronomy education departments has been increasing recently, it is very difficult to witness employees, who received education in these schools or classes. The real masters of bar keeping business are passing away one by one due to their advancing ages. 
Today, where a few masters remain, they may be commissioned in training programs to forward their knowledge to the next generation. It should always be remembered that it is the culture, not the meyhane operators, which needs to be protected.

\section{References}

Aras, A. N. 2018. "Meyhane ve Restoran Görüşme Metinleri” Türkiye Turizmi Sözlü Tarih Araştırması, Cilt 8. 418427. Edited by N. Kozak. İstanbul: Yikılmazlar Basın Yayıncılık.

Arslan, R. 2018. “Meyhane ve Restoran Görüşme Metinleri” Türkiye Turizmi Sözlü Tarih Araştırması, Cilt 8. 628-637. Edited by N. Kozak. İstanbul: Y1kılmazlar Basın Yayıncılık.

BalıkhaneNazırı Ali Rıza Bey. 1973. Bir Zamanlar İstanbul, Hazırlayan N. A. Banoğlu, İstanbul: Tercüman 1001 TemelEser.

Belge, M. 2001. Tarih Boyunca Yemek Kültürü, İstanbul: İletişimYayınları.

Chrzan, J. 2014. Alcohol Social Drinking in Cultural Context. New York: Routledge.

Hür, A. 2011. “İçki Bütün Cürümlerin Anası' Mıdır?” "Sözcü” January 15, 2019. https://www.sozcu18.com/ickibutun-curumlerin-anasi-midir-2066h.htm

İnciyan, D. 2018. "Meyhane ve Restoran Görüşme Metinleri” Türkiye Turizmi Sözlü Tarih Cilt 8. 628-637. Edited by N. Kozak. İstanbul: Yıkılmazlar Basın Yayıncılık.

Kaliç, S. 2012. Tarihimizdeki Garip Olaylar, İstanbul: Maya Kitap

Kalkan, E. 2018. "Meyhane ve Restoran GörüşmeMetinleri” TürkiyeTurizmi Sözlü Tarih Araştırması, Cilt 8. 538-550. Edited by N. Kozak. İstanbul: Yikılmazlar Basın Yayıncılık.

Kızıltay, A. 2018. "Meyhane ve Restoran GörüşmeMetinleri” Türkiye Turizmi Sözlü Tarih Araştırması, Cilt 8. 395408. Edited by N. Kozak. İstanbul: Y1kılmazlar Basın Yayıncılık.

Koçu, R. E. 1971 "GedikliMeyhaneler" "In İstanbul Ansiklopedisi, Cilt 11,” edited by R. E. Koçu, 6064-6069., İstanbul: KoçuYayınları

Morgül. T. 2018. "Meyhane ve Restoran Görüşme Metinleri” Türkiye Turizmi Sözlü Tarih Araştırması, Cilt 8. 638-649. Edited by N. Kozak. İstanbul: Yıkılmazlar Basın Yayıncılık.

Morgül T. and Saç Y. 2012. "İstanbul Meyhaneleri” National Geographic, September: 123-140.

Turan, N. S. 2012 “Geleneksel Toplumda Yasağın Cazibesi Osmanlı Toplumunda İçki.” EvrenselKültür, 252, 38-42.

Ortayl1, İ. 1986. İstanbul'dan Sayfalar, İstanbul'un Meyhaneleri, İstanbul: HilYayınları.

Roden, C. 2005. Arabesque: A Taste of Morocco, Turkey and Lebanon, New York: Alfred A. Knopf.

Ross, F. 2011. "Bulgaria", In Food Cultures of The World Encyclopedia Vol. 2, edited by Ken, A. 61-70. California: Greenwoods.

Şavkay, Tuğrul 2002. EskiMeyhanelerNeden $\mathrm{Bu}$ Kadar ÇekiciydiAcaba? Hürriyet. June 28, 2018 http://hurarsiv.hurriyet.com.tr/goster/haber.aspx?id=87545

Şimşek, T. T. 2018. "Meyhane ve Restoran Görüşme Metinleri” Türkiye Turizmi Sözlü Tarih Araştırması, Cilt 8. 650664. Edited by N. Kozak. İstanbul: Yıkılmazlar Basın Yayıncılık.

Tapper, R. 2000 "Blood, Wine and Water: Social and Symbolic Aspects of Drinks and Drinking in the Islamic Middle East" In Ataste Of Thyme: Culinary Culture of The Middle East, edited by S. Zubaida and R. Tapper, 214-222. London: Tauris Parke Paperbacks.

Tapper, R. and Zubaida, S. (2000) "Giriș.," In OrtadoğuMutfakKültürleriIçinde, edited by S. Zubaida and R. Tapper, 16-17. trans. Ülkün T., İstanbul: TarihVakfi Yurt Yayınları.

Tekin, E. 2018. "Meyhane ve Restoran Görüşme Metinleri” Türkiye Turizmi Sözlü Tarih Araştırması, Cilt 8. 498-508. Edited by N. Kozak. İstanbul: Yıkılmazlar Basın Yayıncılık.

Ünsal, A. 2002. "OsmanlıMutfağı." In YemekKitabı: Tarih-Halkbilim-Edebiyat, 103-11. Hazırlayan: M. S. Koz. İstanbul: Kitabevi.

Yılmaz, F. 2005 "Boş Vaktiniz Var Mı Veya XVI.Yüzyılda Anadolu'da Şarap, Eğlence ve Suç”, Tarih ve Toplum, 1. 11-49.

Zat V. 2014. Adabıyla Rakı ve Çilingir Sofrası, 8. Bask1, İstanbul: İletişimYayınları.

Zat, E.2013. RakıKitabı, İstanbul: OverteamYayınları.

Zat, E. 2018. "Meyhane ve Restoran Görüşme Metinleri” Türkiye Turizmi Sözlü Tarih Araştırması, Cilt 8. 509-528. Edited by N. Kozak. İstanbul: Yıkılmazlar Basın Yayıncılık.

Zat, V. 1994a. "İçki.", In DündenBugüne İstanbul Ansiklopedisi, Cilt 5, edited by N. Akbayar, E. Işın and N. Sakoğlu, 131-132. İstanbul: Kültür Bakanlığ 1 ve Tarih VakfiY ayını.

Zat, V. 1994b. "Meyhane.”, In Dünden Bugüne İstanbul Ansiklopedisi, Cilt. 4, edited by N. Akbayar, E. Işın and N. Sakoğlu, 72-84. İstanbul: Kültür Bakanlığı ve Tarih Vakfi Yayını.

Zat, V. 2002. Eski İstanbul Meyhaneleri, İstanbul: İletişimYayınları.

Zat, V. 2008. Biz Raki Içeriz, İstanbul: OverteamYayınları. 